\section{(A) Check for updates}

Cite this: Dalton Trans., 2018, 47 7721

Received 5th February 2018 Accepted 30th April 2018

DOI: $10.1039 / c 8 d t 00490 k$ rsc.li/dalton

\title{
Synthesis, characterisation and thermal properties of Sn(II) pyrrolide complexes $\uparrow$
}

\author{
James D. Parish, ${ }^{a}$ Michael W. Snook, ${ }^{a}$ Andrew L. Johnson (D) *a and \\ Gabriele Kociok-Köhn ${ }^{\mathrm{b}}$
}

\begin{abstract}
$\mathrm{SnO}$ is a rare example of a stable p-type semiconductor material. Here, we describe the synthesis and characterisation of a family of Sn(I) pyrrolide complexes for future application in the MOCVD and ALD of tin containing thin films. Reaction of the $\mathrm{Sn}(\|)$ amide complex, $\left[\left\{\left(\mathrm{Me}_{3} \mathrm{Si}\right)_{2} \mathrm{~N}\right\}_{2} \mathrm{Sn}\right]$, with the $\mathrm{N}, \mathrm{N}$-bidentate pyrrole pro-ligand, $\mathrm{L}^{1} \mathrm{H}$, forms the hetero- and homoleptic complexes $\left[\left\{\mathrm{L}^{1}\right\} \mathrm{Sn}\left\{\mathrm{N}\left(\mathrm{SiMe}_{3}\right)_{2}\right\}\right](\mathbf{1})$ and $\left[\left\{\mathrm{L}^{1}\right\} 2 \mathrm{Sn}\right]$ (2), respectively, bearing the 2-dimethylaminomethyl-pyrrolide ligand $\left(\mathrm{L}^{1}\right)$. Reaction of $\left.\left[\left\{\left(\mathrm{Me}{ }_{3} \mathrm{Si}\right)_{2} \mathrm{~N}\right)\right\}_{2} \mathrm{Sn}\right]$ with the pyrrole-aldimine pro-ligands, $\mathrm{L}^{2} \mathrm{H}-\mathrm{L}^{7} \mathrm{H}$, results in the exclusive formation of the homoleptic bispyrrolide complexes $\left[\left\{\mathrm{L}^{2-7}\right\}_{2} \mathrm{Sn}\right](\mathbf{3}-\mathbf{8})$. All complexes have been characterised by elemental analysis and NMR spectroscopy, and the molecular structures of complexes 1-5 and $\mathbf{8}$ are determined by single crystal X-ray diffraction. TG analysis and isothermal TG analysis have been used to evaluate the potential utility of these systems as MOCVD and ALD precursors.
\end{abstract}

\section{Introduction}

Transparent semiconducting oxide (TSO) thin films have attracted considerable interest due to their omnipresence in modern technology, finding wide-spread application in solar cells, light emitting diodes, flat panel displays, optical communicators, gas sensors and thin film transistors. ${ }^{1}$ The majority of commercially available semiconducting oxides are n-type, e.g. ZnO; many potential applications of TSOs are still limited by the scarcity of p-type counterparts. ${ }^{2}$ The development of high performance p-type TSOs would leverage the inordinate potential of oxides for transparent electronics and optoelectronics by combining them with n-type TSOs in $\mathrm{p}-\mathrm{n}$ heterojunctions. ${ }^{3}$ The recent rapid development of both photovoltaics and solar water splitting also calls for p-type electrodes for more efficient hole collection. ${ }^{4}$ However, the most significant challenge in the realisation of this goal is the paucity of suitable p-type TSOs. To this end, a great deal of experimental work has focused on the development of p-type semiconducting materials such as $\mathrm{SnO}, \mathrm{Cu}_{2} \mathrm{O}$ and $\mathrm{N}$-doped $\mathrm{ZnO}^{2,4,5}$ Unfortunately, all these metastable materials suffer from an intrinsic instability towards oxidation. Despite this, SnO which

\footnotetext{
${ }^{a}$ Department of Chemistry, University of Bath, Claverton Down, Bath, BA2 7AY, UK. E-mail: A.L.Johnson@bath.ac.uk

${ }^{b}$ Chemical Characterisation and Analysis Facility, Department of Chemistry, University of Bath, Claverton Down, Bath, BA2 7AY, UK

$\dagger$ Electronic supplementary information (ESI) available. CCDC 1820591-1820596. For ESI and crystallographic data in CIF or other electronic format see DOI: $10.1039 / \mathrm{c} 8 \mathrm{dt} 00490 \mathrm{k}$
}

possesses a layered PbO-like litharge structure has received considerable attention as a p-type semiconductor. ${ }^{1 c, 2,5,6}$ Interest was initially sparked by $\mathrm{SnO}$ grown on yttria stabilised $\mathrm{ZrO}_{2}$ (YSZ) reportedly displaying a Hall mobility of $2.4 \mathrm{~cm}^{2} \mathrm{~V}^{-1} \mathrm{~s}^{-1}$ and with a field effect mobility of $1.3 \mathrm{~cm}^{2} \mathrm{~V}^{-1} \mathrm{~s}^{-1}$, when used as a p-channel thin film transistor (TFT). ${ }^{7}$ More recently, Hall mobility values as high as $\sim 18.71 \mathrm{~cm}^{2} \mathrm{~V}^{-1} \mathrm{~s}^{-1}$ and field effect mobilities of $6.75 \mathrm{~cm}^{2} \mathrm{~V}^{-1} \mathrm{~s}^{-1}$ have been reported. ${ }^{8}$

Physical vapour deposition (PVD) $)^{8,9}$ and chemical vapour deposition (CVD) ${ }^{10}$ have both been used to produce thin films of SnO with varying degrees of success. Since modern devices are topographically diverse structures, a vapor phase technique capable of producing thin films with exceptional conformality is required. Atomic layer deposition (ALD), and to a lesser extent metal-organic chemical vapor deposition (MOCVD), offer such a solution. However, $\mathrm{SnO}$ is intrinsically reactive towards oxygen, and formation of both $\mathrm{Sn}_{2} \mathrm{O}_{3}$ and $\mathrm{SnO}_{2}$ as phase impurities results in thin films with undesirable properties. ${ }^{10 g}$ Therefore, precise control over the oxidation state of the metal is paramount. Whilst a number of Sn-precursor/reactant combinations have been surveyed for the growth of SnO, the majority have focused on the utility of $\mathrm{Sn}(\mathrm{Iv})$ precursor combinations, e.g. $\mathrm{SnCl}_{4} / \mathrm{H}_{2} \mathrm{O}^{11} / \mathrm{H}_{2} \mathrm{O}_{2}{ }^{12} \mathrm{SnI}_{4} / \mathrm{O}_{2},{ }^{13} \mathrm{Sn}\left(\mathrm{NMe}_{2}\right)_{4} /$ $\mathrm{H}_{2} \mathrm{O} / \mathrm{H}_{2} \mathrm{O}_{2},{ }^{14} \operatorname{SnEt}_{4} / \mathrm{H}_{2} \mathrm{O}_{2} / \mathrm{O}_{2} / \mathrm{O}_{3}$-plasma and $\mathrm{Bu}_{3}$ SnOEt $/ \mathrm{O}_{3} .{ }^{15}$ Of the precursor/reactant combinations investigated, only three have utilised Sn(II) precursors (Fig. 1): in the case of the stannylene complex (A), reaction with $\mathrm{H}_{2} \mathrm{O}$ failed to produce $\mathrm{SnO}$, and reaction with either $\mathrm{H}_{2} \mathrm{O}_{2}{ }^{16}$ or $\mathrm{NO}^{17}$ resulted in the formation of a mixed phase of $\mathrm{SnO} / \mathrm{SnO}_{2}$ (i.e. $\mathrm{SnO}_{x}$ ). Similarly, $\mathrm{Sn}$ $(\mathrm{HMDS})_{2}(\mathbf{B})$ has also been used in conjunction with either 


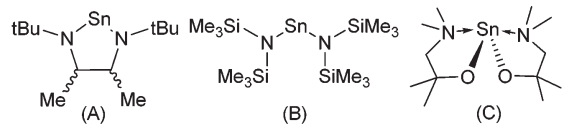

Fig. 1 Molecular structures of the three reported Sn(॥) ALD precursors which have been used to produce tin oxide thin films.

$\mathrm{H}_{2} \mathrm{O}$ or $\mathrm{O}_{3}$ in an ALD process to deposit $\mathrm{Sn}$ (II) and $\mathrm{Sn}$ (Iv) oxides and $\mathrm{SiO}_{2}$ mixes between 80 and $250{ }^{\circ} \mathrm{C} .{ }^{18}$ To date, only the Sn(II) aminoalkoxide complex (C) has been found to produce phase pure $\mathrm{SnO}$ in an ALD process, with $\mathrm{H}_{2} \mathrm{O}$, between $90{ }^{\circ} \mathrm{C}$ and $210{ }^{\circ} \mathrm{C}$, with crystallinity occurring above $150{ }^{\circ} \mathrm{C} .{ }^{19}$ This dearth of suitable precursors for SnO production has prompted us, and others, ${ }^{20}$ to investigate new Sn(II)-ligand combinations. In an attempt to optimise precursor reactivity and thermal stability, we chose to investigate the utility of the amino-pyrrolide $\left(\mathrm{L}^{1}\right)$ and pyrrolylaldiminato ligands $\left(\mathrm{L}^{2}-\mathrm{L}^{6}\right)$ shown in Scheme $1 .^{21}$ The ligands $\left(\mathrm{L}^{1}-\mathrm{L}^{6}\right)$ can be tuned by the substitution of the $\mathrm{R}$ groups to limit oligomerisation and tune volatility. The bidentate chelating effect should increase the thermal stability of the resulting metal compounds. Whilst numerous metal compounds with pyrrole ligands can be found in the literature, their application as CVD or ALD precursors is limited to selected titanium, ${ }^{22}$ barium $^{23}$ and copper(I) ${ }^{24}$ complexes. To date, $\mathrm{Sn}$ (II)-pyrrolide systems are limited to the stannocene complex $\left[\mathrm{Sn}\left\{\eta^{5}-2,5-\mathrm{NC}_{4}{ }^{t} \mathrm{Bu}_{2} \mathrm{H}_{2}\right\}_{2}\right],{ }^{25}$ and the carbonyl-substituted pyrrolide complexes, $\left[\mathrm{Sn}\left\{\kappa^{2-} N, O-\mathrm{NC}_{4} \mathrm{H}_{3} \mathrm{CH}(\mathrm{O})\right.\right.$ $\left.\mathrm{R}_{2}\right]$ ( $\mathrm{R}=\mathrm{NMe}_{2}$ or $\left.\mathrm{Me}\right) .{ }^{26}$ Here we describe the details of the synthesis and structure of a series of bidentate pyrrolide based $\mathrm{Sn}$ (II) complexes, including investigations into their thermal properties.

\section{Results and discussion}

\section{Synthesis of tin(II) complexes}

In all cases, isolated products were characterised by solution state NMR $\left({ }^{1} \mathrm{H},{ }^{13} \mathrm{C}\right.$ and $\left.{ }^{119} \mathrm{Sn}\right)$ spectroscopy and elemental ana-
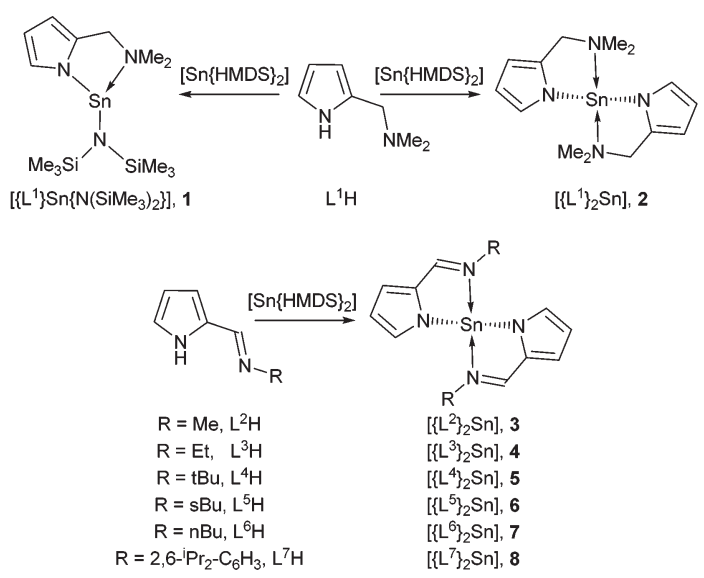

Scheme 1 lysis. Initial attempts to prepare the mono(dimethylamido) $\mathrm{Sn}$ (II) compounds by a direct stoichiometric $(1: 1)$ reaction of bis(dimethylamido)tin(II) with the pyrrole ligands, $\mathrm{L}^{1} \mathrm{H}-\mathrm{L}^{7} \mathrm{H}$, in both hexane and THF, respectively, were unsuccessful. However, reactions did result in the formation of bis(pyrrolide) compounds 2-8. We attribute this failure to prepare the dimethylamido-tin(II) species to the stronger acidity of the pyrrole $\{\mathrm{N}-\mathrm{H}\}$ relative to that of the dimethylamine hydrogen, combined with the enhanced basicity of the dimethylamide group in the monoamide intermediate, [\{pyrrolide $\left.\} \mathrm{Sn}-\mathrm{NMe}_{2}\right]$, relative to $\left[\mathrm{Sn}\left\{\mathrm{NMe}_{2}\right\}_{2}\right]$.

In contrast, the reaction of the bulkier and less basic amide system $\left[\mathrm{Sn}\left\{\mathrm{N}\left(\mathrm{SiMe}_{3}\right)_{2}\right\}_{2}\right]$ with the ligand $\mathrm{L}^{1} \mathrm{H}$ in a stoichiometric 1:1 reaction results in the formation, and isolation after recrystallisation, of the mono-pyrrolide complex $\mathbf{1}$. The ${ }^{1} \mathrm{H}$ NMR spectrum of $\mathbf{1}$ clearly shows the presence of a singlet resonance at $\delta=0.25 \mathrm{ppm}$ representative of the presence of a $\{\mathrm{HMDS}\}$ group, in an $18 \mathrm{H}: 3 \mathrm{H}$ ratio with the dimethylamine group, $\left\{\mathrm{NMe}_{2}\right\}$, associated with $\left\{\mathrm{L}^{1}\right\}(\delta=1.76 \mathrm{ppm})$, indicative of the presence of the $\left\{\mathrm{L}^{1}\right\}$ and $\{$ HMDS $\}$ ligands in a $1: 1$ ratio. A comparable reaction of $\left[\mathrm{Sn}\{\mathrm{HMDS}\}_{2}\right]$ in an equimolar reaction with $\mathrm{L}^{2} \mathrm{H}-\mathrm{L}^{8} \mathrm{H}$ results in the formation of the bis-pyrrolide complexes, 2-8, in yields $<50 \%$, suggestive of a Schlenk equilibrium in which the putative mono-amide intermediates are unstable with respect to disproportionation, and formation of the bis-pyrrole complex. The ${ }^{1} \mathrm{H}$ NMR spectra of $2-8$ clearly show the absence of resonances associated with the $\{$ HMDS ligands and are consistent with the formation of the bispyrrole complexes. In the case of the sec-Bu derivative complex, 6, a racemic ( \pm )sec-butyl amine was used for the synthesis of the proligand $\mathrm{L}^{5} \mathrm{H}$, resulting in the ${ }^{1} \mathrm{H}$ and ${ }^{13} \mathrm{C} \mathrm{NMR}$ spectra containing two sets of resonances corresponding to the presence of the associated $(R, R / S, S$ and $R, S / S, R)$ stereoisomers in solution. Elemental analysis confirms the formation of the bis-pyrrole complexes. The intrinsic $C_{2}$ symmetry of complexes 2-7 is negated somewhat in solution by a rapid, socalled, "flip-flop" equilibrium process in which the $\mathrm{N} \rightarrow \mathrm{Sn}$ coordination bonds repeatedly open and close. In compound 8, however, the methyl and methine groups of the isopropyl substituents display a series of convoluted multiplets $(\delta=$ 0.89-1.36 ppm, 12H), alongside two broad resonances respectively $(\delta=3.00 \mathrm{ppm}, 1 \mathrm{H}$; and $3.43 \mathrm{ppm}, 1 \mathrm{H}$ ) suggestive of a slow rotation, on the NMR timescale, about the $\mathrm{N}-\mathrm{C}_{(\text {phenyl })}$ bond. The stoichiometric reaction $(2: 1)$ of the pro-ligands, $\mathrm{L}^{1} \mathrm{H}-\mathrm{L}^{7} \mathrm{H}$, with $\left[\mathrm{Sn}\left\{\mathrm{HMDS}_{2}\right]\right.$ produces the expected complexes cleanly in moderate to high yields (64-87\%).

\section{Solid state structures}

X-ray diffraction studies of single crystals of complexes 1, 2, 3, 4, 5 and 8 unambiguously established their solid state structures. The structures of the heteroleptic and the homoleptic complexes $\left[\mathrm{Sn}\left\{\kappa^{2}-N, N-\mathrm{NC}_{4} \mathrm{H}_{3} \mathrm{CH}_{2} \mathrm{NMe}_{2}\right\}\left\{\mathrm{N}\left(\mathrm{SiMe}_{3}\right)_{2}\right\}\right]$ (1) and $\left[\mathrm{Sn}\left\{\mathrm{\kappa}^{2}-\mathrm{N}, \mathrm{N}-\mathrm{NC}_{4} \mathrm{H}_{3} \mathrm{CH}_{2} \mathrm{NMe}_{2}\right\}_{2}\right]$ (2) are shown in Fig. 2. While compounds 1 and 2 are both chiral, the enantiomers co-crystallise in noncentrosymmetric space groups. 


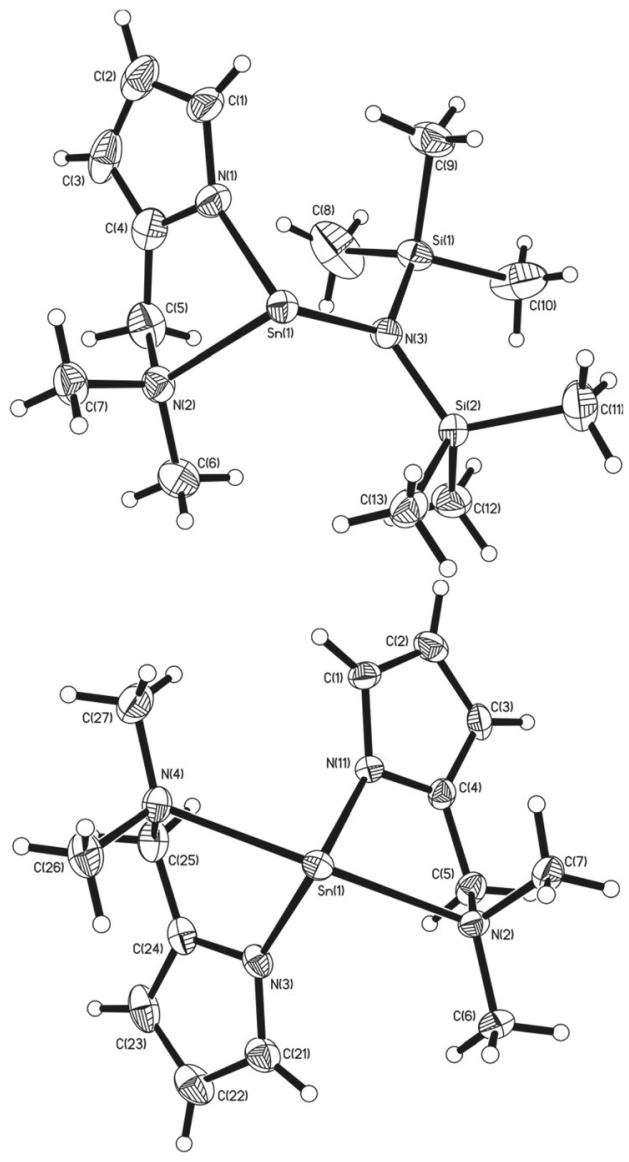

Fig. 2 The molecular structures of complex 1 (top) and 2 (bottom) (50\% probability ellipsoids).

In the solid state, $\mathbf{1}$ crystallises in the monoclinic space group $P 2_{1} / c$. The asymmetric unit cell contains a single monomeric complex with a three coordinate, pseudo-trigonal-pyramidal geometry about the $\mathrm{Sn}$ (II) centre, with the $\left\{\mathrm{L}^{1}\right\}^{-}$ligand coordinated in a $\kappa^{2}$ fashion via the pyrrolide nitrogen and the pendant $\left\{\mathrm{NMe}_{2}\right\}$ group, as well as the nitrogen of the $\{\mathrm{HMDS}\}$ ligand, in a terminal bonding mode (Fig. 2).
The $\operatorname{Sn}(1)-\mathrm{N}(1)$ (2.152) and $\mathrm{Sn}(1)-\mathrm{N}(3)$ (2.127) bond lengths are comparable to those already reported for Sn-amide compounds, ${ }^{27}$ whereas the dative $\mathrm{Sn}(\mathrm{II}) \leftarrow \mathrm{NMe}_{2}$ bond $[\mathrm{Sn}(1)-\mathrm{N}(2)$ (2.418)] is expectedly longer. Despite a constrained bite angle for the $\left\{\mathrm{L}^{1}\right\}^{-}$ligand $\left[\mathrm{N}(1)-\mathrm{Sn}(1)-\mathrm{N}(2)\left(74.52^{\circ}\right)\right]$, the $\mathrm{N}-\mathrm{Sn}-\mathrm{N}$ bond angles in $1\left[\mathrm{~N}(1)-\mathrm{Sn}(1)-\mathrm{N}(3)\left(96.36^{\circ}\right)\right.$ and $\mathrm{N}(2)-\mathrm{Sn}(1)-\mathrm{N}(3)$ $\left(96.84^{\circ}\right)$ ] suggest the absence of sp-hybridisation at the $\mathrm{Sn}$ (II) centre and that the tin-ligand bonds almost exclusively involve the p-orbitals; the nature of the electron lone pair in compound 1 can therefore be considered as essentially a $5 \mathrm{~s}^{2}$ configuration and therefore non-directional.

Complex 2, which has intrinsic $C_{2}$ symmetry, crystallises in the monoclinic space group $P 2_{1} / c$ and is shown in Fig. 2. Here the asymmetric unit cell contains a single molecule of the complex with a four coordinate, pseudo-trigonal bipyramidal geometry $(\tau=0.83)^{28}$ in which the two $\left\{\mathrm{L}^{1}\right\}^{-}$ligands are coordinated in the same $\kappa^{2}$ fashion observed in $\mathbf{1}$, with the $\mathrm{N}$-atoms of the pyrrolide ligands occupying two equatorial, and the pendant $\left\{\mathrm{NMe}_{2}\right\}$ groups occupying the axial positions. A cursory analysis of the bond angles about the $\mathrm{Sn}$ (II) centre in $2\left[\mathrm{~N}(1)-\mathrm{Sn}(1)-\mathrm{N}(3)\left(97.44^{\circ}\right) \& \mathrm{~N}(2)-\mathrm{Sn}(1)-\mathrm{N}(3)\left(147.21^{\circ}\right)\right]$ again suggests that the tin-ligand bonds almost exclusively involve the p-orbitals on Sn, and that the lone pair of electrons in 2 is therefore again essentially $5 \mathrm{~s}^{2}$ based. The $\mathrm{Sn}-\mathrm{N}_{\mathrm{py}}[\mathrm{Sn}(1)-\mathrm{N}(1)$ $\left.\left(2.179^{\circ}\right) \& \operatorname{Sn}(1)-\mathrm{N}(3)\left(2.165^{\circ}\right)\right]$ and $\mathrm{Sn} \leftarrow \mathrm{NMe}_{2} \quad[\operatorname{Sn}(1)-\mathrm{N}(2)$ $\left.\left(2.516^{\circ}\right) \& \mathrm{Sn}(1)-\mathrm{N}(4)\left(2.528^{\circ}\right)\right]$ bond lengths in 2 are commensurate with 1 and comparable complexes.

For the imine complexes $\mathbf{3 , 4}$ and $\mathbf{5}$, which are structurally related to 2, the molecular structures are shown in Fig. 3. For complexes $\mathbf{3}$ and 5, which crystallise in the centrosymmetric space group $P 2_{1} / n$, the asymmetric unit cell contains one full molecule of the bis-(pyrrolylaldiminate)Sn(II) complex. Complexes 3 and 5 are disordered such that all ligand atoms, with the exception of $\operatorname{Sn}(1), \mathrm{N}(1)$ and $\mathrm{N}(3)$, exhibit $67: 33$ and $80: 20$ disorder, respectively, via a pseudo-mirror plane containing the three non-affected atoms. Complex 4 crystallises in the polar space group $P 2_{1}$ with only one enantiomer of the chiral complex in the crystals, while in all three cases, the central Sn(II) atoms are four-coordinate; analysis of the bond angles about the tin centre suggests a trigonal bipyramidal

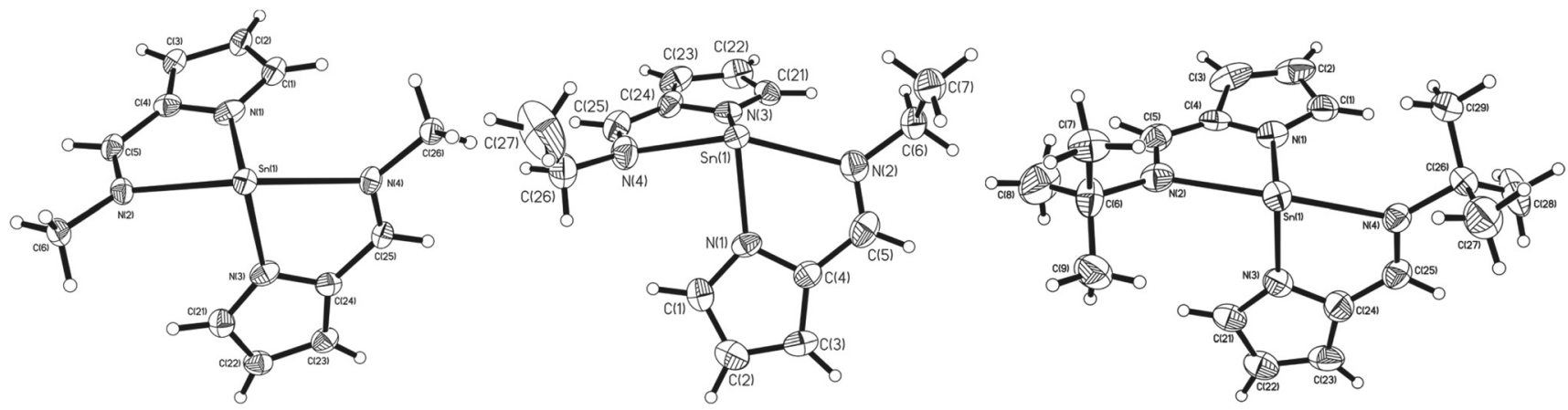

Fig. 3 The molecular structures of complex 3 (40\% probability ellipsoids), 4 (50\% probability ellipsoids) and 5 (50\% probability ellipsoids). Complexes 3 and 5 are disordered such that all ligand atoms, with the exception of Sn(1), N(1) and N(3), exhibited $67: 33$ and $80: 20$ disorder, respectively, via a pseudo-mirror plane containing the three non-affected atoms. The major component only is depicted for clarity. 
Table 1 Selected bond lengths $(\AA \AA)$ and bond angles $\left({ }^{\circ}\right)$ for complexes 1-5 and 8

\begin{tabular}{|c|c|c|c|c|c|c|}
\hline & 1 & 2 & $3^{a}$ & 4 & $5^{a}$ & 8 \\
\hline $\operatorname{Sn}(1)-N(1)$ & $2.152(2)$ & $2.179(2)$ & $2.181(3)$ & $2.171(5)$ & $2.185(4)$ & $2.3138(16)$ \\
\hline $\operatorname{Sn}(1)-\mathrm{N}(3)$ & $2.127(2)$ & $2.165(2)$ & $2.186(3)$ & $2.167(5)$ & $2.165(4)$ & $2.2871(16)$ \\
\hline $\operatorname{Sn}(1)-\mathrm{N}(4)$ & - & $2.528(2)$ & $2.439(3)$ & $2.375(7)$ & $2.442(5)$ & $2.3127(15)$ \\
\hline \multirow[t]{2}{*}{$\mathrm{N}=\mathrm{C}$} & - & - & $1.294(6)$ & $1.279(12)$ & $1.300(10)$ & $1.297(2)$ \\
\hline & & & $1.280(5)$ & $1.302(11)$ & $1.273(10)$ & $1.304(2)$ \\
\hline $\mathrm{N}(2)-\mathrm{Sn}(1)-\mathrm{N}(3)$ & $96.84(8)$ & $86.71(8)$ & $84.73(10)$ & $86.3(2)$ & $88.31(17)$ & $81.34(5)$ \\
\hline $\mathrm{N}(3)-\mathrm{Sn}(1)-\mathrm{N}(4)$ & - & $72.16(8)$ & $70.26(11)$ & $72.1(2)$ & $73.54(17)$ & $71.84(6)$ \\
\hline $\mathrm{N}(1)-\mathrm{Sn}(1)-\mathrm{N}(3)$ & $96.36(8)$ & $97.44(8)$ & $92.17(10)$ & 95.64(19) & $88.33(15)$ & $127.03(6)$ \\
\hline $\mathrm{N}(2)-\mathrm{Sn}(1)-\mathrm{N}(4)$ & - & $147.21(7)$ & $142.69(11)$ & $144.9(2)$ & $151.8(2)$ & $117.62(5)$ \\
\hline
\end{tabular}

${ }^{a}$ Complexes 3 and 5 are disordered such that all ligand atoms, with the exception of Sn(1), N(1) and N(3), exhibited $67: 33$ and $80: 20$ disorder respectively, via a pseudo-mirror plane containing the three non-affected atoms. Only the major component is shown here for clarity.

geometry $^{28}[3: \tau=0.92,4: \tau=0.82,5: \tau=1.06]$ with the imine nitrogen atoms occupying the axial coordination sites and the pyrrole nitrogen atoms the equatorial positions. While the $\mathrm{N}_{\text {(imine) }}-\mathrm{Sn}-\mathrm{N}_{(\text {imine) }}$ bond angles increase from $\sim 143^{\circ}$ to $152^{\circ}$ as the imine substituent changes from methyl to ethyl and $t$-butyl, respectively, the $\mathrm{N}_{\mathrm{py}}-\mathrm{Sn}-\mathrm{N}_{\mathrm{py}}$ angles [3: 92.17(10) ${ }^{\circ}, 4$ : 95.64 $(19)^{\circ}, 5: 88.33(15)^{\circ}$ ] are all around $90^{\circ}$ suggesting that the $\mathrm{Sn}-\mathrm{N}_{\mathrm{py}}$ bonds involve mostly the $\mathrm{Sn}$ (II) p-orbitals. The $\mathrm{Sn}-\mathrm{N}_{\mathrm{py}}$ and $\mathrm{Sn} \leftarrow \mathrm{NR}$ bond lengths (shown in Table 1) are all similar, ibid.

Similarly to complexes $\mathbf{2 - 5}$, compound $\mathbf{8}$ is chiral (Fig. 4), possessing molecular $C_{2}$ symmetry; the other enantiomer is also formed in the product, with $\mathbf{8}$ crystallising in the centrosymmetric monoclinic space group $P 2_{1} / n$. Exhibiting a 4 -coordinate $\mathrm{Sn}$ (II) centre, the geometry about the $\mathrm{Sn}$ (II) atom is best described as square based pyramidal $[\tau=0.15]$. Interestingly, the $\mathrm{Sn}-\mathrm{N}_{\text {py }}$ bonds in $8[\operatorname{Sn}(1)-\mathrm{N}(1)=2.3138(16) \AA, \operatorname{Sn}(1)-\mathrm{N}(3)=$ $2.2871(16) \AA]$ are significantly longer than those reported for 1-5. Similarly, the $\mathrm{Sn} \leftarrow \mathrm{NR}$ bonds are also significantly longer $[\mathrm{Sn}(1)-\mathrm{N}(2)=2.3308(16) \AA, \operatorname{Sn}(1)-\mathrm{N}(4)=2.3127(15) \AA]$ than those observed in 3-5. Consistent with this observation, the

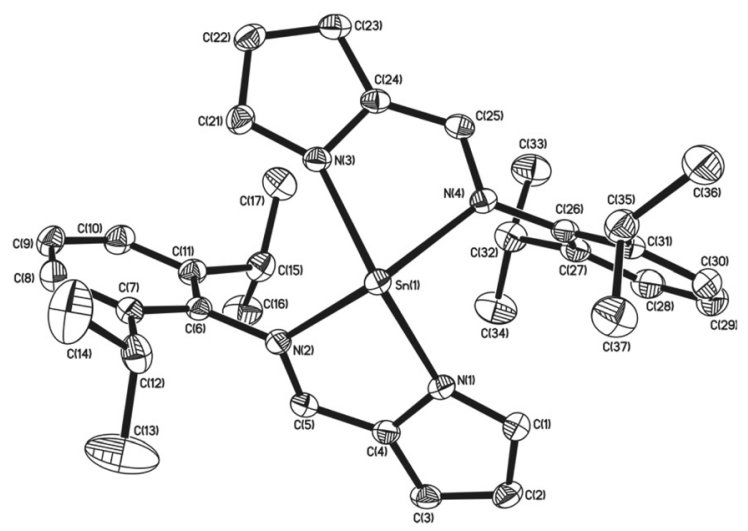

Fig. 4 The molecular structures of complex 8 (50\% probability ellipsoids), hydrogen atoms have been omitted for clarity.
$\mathrm{N}_{\mathrm{py}}-\mathrm{Sn}-\mathrm{N}_{\mathrm{py}}$ and $\mathrm{N}_{\text {(imine) }}-\mathrm{Sn}-\mathrm{N}_{\text {(imine) }}$ angles observed in $\mathbf{8}$ are both close to $120^{\circ}\left[127.03(6)^{\circ}\right.$ and $117.62(5)^{\circ}$ respectively], suggesting that the tin-ligand bonds almost exclusively involve $\mathrm{sp}^{2}$ hybridised orbitals on the tin, with the lone pair in 8 considered to be essentially based in a directional $\mathrm{sp}^{2}$ orbital.

\section{Thermal profiles}

Two of the main precursor requirements for MOCVD and ALD applications are the need for volatility and thermal stability. ${ }^{29}$ As the primary goal of synthesising compounds 1-8 was driven by our interest in their application as precursors for the MOCVD and ALD of Sn(II) oxide films, melting point analysis, thermogravimetric analysis (TGA) and isothermal studies were employed to investigate the volatility and thermal stability of complexes 1-8. The melting points and analysis of compounds 1-8 were recorded with instruments housed in an argon filled glove-box in order to minimise reaction with atmospheric moisture/air. For the amino-pyrrolide complexes $\mathbf{1}$ and 2, results suggest that these materials are unsuitable for application as ALD precursors. Table 2 shows the melting and decomposition points for these complexes. Complex 1 displays a rather low decomposition temperature $\left(100^{\circ} \mathrm{C}\right)$ quite close to

Table 2 Physical properties of the Sn(II) pyrrolide complexes 1-8

\begin{tabular}{|c|c|c|c|}
\hline Compound $\mathrm{R}=$ & $\begin{array}{l}\text { Melting point } \\
\left({ }^{\circ} \mathrm{C}\right)\end{array}$ & $\begin{array}{l}\text { Decompn } \\
\text { point }\left({ }^{\circ} \mathrm{C}\right)\end{array}$ & $\begin{array}{l}\text { Evaporation } \\
\operatorname{rate}^{a}\left(\mu \mathrm{g} \mathrm{min} \mathrm{min}^{-1} \mathrm{~cm}^{-2}\right)\end{array}$ \\
\hline (1) & 95 & $\sim 100$ & - \\
\hline (2) & - & $\sim 50$ & - \\
\hline -Me (3) & - & 140 & $6.409(8)$ \\
\hline -Et (4) & 130 & 137 & 19.894(1) \\
\hline${ }_{-}^{t} \mathrm{Bu}(5)$ & - & 141 & $19.974(7)$ \\
\hline$-{ }^{n} \mathrm{Bu}(6)$ & 85 & 100 & $14.085(8)$ \\
\hline$-{ }^{s} \mathrm{Bu}(7)$ & Viscous oil & 94 & $5.611(6)$ \\
\hline -Dipp (8) & 153 & 290 & $2.357(5)$ \\
\hline$-\operatorname{Dipp}(8)^{b}$ & & & $12.653(9)$ \\
\hline
\end{tabular}

${ }^{a}$ Isothermal TGA recorded at $130{ }^{\circ} \mathrm{C} .{ }^{b}$ Isothermal TGA recorded at $160^{\circ} \mathrm{C}$. 


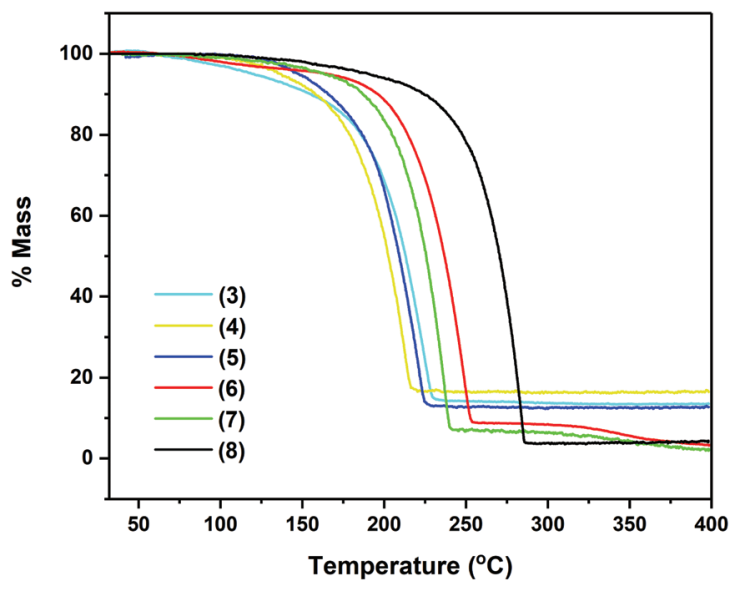

Fig. 5 Thermogravimetric analysis data for complexes 3-8.

its melting point $\left(95{ }^{\circ} \mathrm{C}\right)$. Similarly for 2 , a relatively low decomposition $\left(50^{\circ} \mathrm{C}\right)$ was observed before any phase transition could be detected, suggesting the possible lack of utility of these systems as ALD precursors. Despite this observation, the TGA of Sn(II)bis-(pyrrolide) 2-8 was performed in order to gain greater insight into the relative volatilities and thermal stabilities of the compounds.

As seen in Fig. 5, compounds 3-8 exhibit very similar thermal behaviour, consistent with single step evaporation. For all precursors, the onset of volatilisation $\left(\sim 100^{\circ} \mathrm{C}\right)$ and the temperature at which the evaporation is completed (between 220 and $255^{\circ} \mathrm{C}$ for $3-7$ and by $286^{\circ} \mathrm{C}$ for 8 ) are similar.

Table 3 shows germane data, relating to the TG analysis of compounds $3-\mathbf{8}$, i.e. \% residual mass and wt $\%$ of $\mathrm{Sn}$ in complexes. Fig. 4 clearly shows that compounds 3-8 exhibit very similar thermal behaviour, undergoing a clear, single mass loss event over a small temperature window to yield stable residues of between 4 and $16.5 \%$, consistent with a single step evaporation process. In the case of complexes 6-8, the final mass residues are considerably lower than the expected mass residue for the production of the Sn metal, strongly suggestive of a high degree of volatility within these systems. For complexes 3-5, the mass residues are proportionately higher although still below the \% mass residue expected if decompo-

Table $3 \%$ Residual mass, wt\% of Sn and onset of mass loss for complexes 3-8

\begin{tabular}{|c|c|c|c|}
\hline Compound $\mathrm{R}=$ & $\begin{array}{l}\text { Residual } \\
\text { mass }\end{array}$ & $\begin{array}{l}\% \text { Sn } \\
\text { by wt }\end{array}$ & $\begin{array}{l}\text { Onset of } \\
\text { mass loss }{ }^{b}\left({ }^{\circ} \mathrm{C}\right)\end{array}$ \\
\hline -Me (3) & 13.5 & 35.7 & 85 \\
\hline -Et (4) & 16.5 & 32.9 & 125 \\
\hline$-{ }_{-}^{t} \mathrm{Bu}(5)$ & 12.7 & 28.5 & 132 \\
\hline$-{ }^{n} \mathrm{Bu}(6)$ & $7.1(2.0)^{a}$ & 28.5 & 95 \\
\hline$-{ }^{s} \mathrm{Bu}(7)$ & $8.7(3.3)^{a}$ & 28.5 & 126 \\
\hline -Dipp (8) & 4.0 & 19.0 & 147 \\
\hline
\end{tabular}

${ }^{a}$ Residual mass after the second mass loss event in TGA.

${ }^{b}$ Temperature at $2 \%$ mass loss. sition resulted in the formation of the Sn metal. Compound 2, which was also analysed, showed a complicated and shallow decomposition profile with mass loss starting at $36^{\circ} \mathrm{C}$. At $400{ }^{\circ} \mathrm{C}$, the residual mass is $\sim 67 \%$, indicative of a non-volatile material with incomplete thermal decomposition (Fig. S1, ESI†े).

Given the nature of the ligand systems involved in $\mathbf{3 - 8}$, it is unlikely that the TGA residues contain oxide products (i.e. $\mathrm{SnO}_{x}$ ), and instead are more likely to be metallic Sn (with possible carbon impurities). This is consistent with the observation of metallic deposits (of Sn) in the TGA crucibles after decomposition studies, suggesting the possible application of these systems in the deposition of metallic tin under a nonoxidative atmosphere.

While the TGA data provide an indication of the volatility of the complexes, decomposition characteristics are less easy to discern for complexes with significant volatility. However, no stepwise decomposition processes are observed in the TGA profiles of 3-8, corresponding to the systematic breakdown of the pyrrolide ring systems, as postulated in other studies. ${ }^{30}$ More relevant investigations have suggested that pyrrolide complexes are susceptible to $\beta$-hydride elimination processes, ${ }^{22}$ in these cases most likely arising from hydride abstraction from the aldimine substituents. This is in contrast to complex 2, which possesses pendant $\left\{\mathrm{CH}_{2} \mathrm{NMe}_{2}\right\}$ groups, and as such does not share the same electronic delocalisation observed for the aldimine systems 3-8. Consequently, the thermal analysis of 2 (ESI $\dagger$ ) shows a stepwise decomposition over a broad temperature range, consistent with the aforementioned decomposition pathway.

Remarkably, no discernible trends are observed between pyrrolide-aldimine substituents and volatilities/stabilities, with the ethyl (3) and $t$-butyl (4) substituted complexes showing the highest volatility followed by the 2,6-diisopropyl-phenyl complex (8). However, it is noteworthy that the aryl containing system, 8, displays a strikingly high thermal stability, in contrast to the other systems investigated here.

We suggest that this high degree of thermal stability is in part due to the absence of a suitable hydride abstraction process, as discussed previously. This observation is the focus of further studies to enhance the thermal stability of selected precursor systems, and to expand the ALD window of selected compounds, whilst inhibiting CVD processes.

The thermal behaviour of complexes 3-8 was further investigated using isothermal TGA studies (Fig. 6). At a fixed temperature of $130{ }^{\circ} \mathrm{C}$, the mass loss for each compound was measured over a period of $120 \mathrm{~min}(2 \mathrm{~h})$. In all measurements, an approximate linear weight loss was observed, which could be indicative of sublimation, with limited signs of decomposition. However, for complexes 6 and 7, visual (m.p. studies) decomposition appears to begin at below $100{ }^{\circ} \mathrm{C}$ (Table 2). From the gradient of the corresponding plots, the evaporation rates at a set temperature of $130^{\circ} \mathrm{C}$ were determined (Table 2). The evaporation rates were found to be in the range of 2.4-20 $\mu \mathrm{g} \mathrm{min}{ }^{-1} \mathrm{~cm}^{-2}$. From the thermal studies, one can conclude that among the $\mathrm{Sn}$ (II) pyrrolide complexes reported here, 


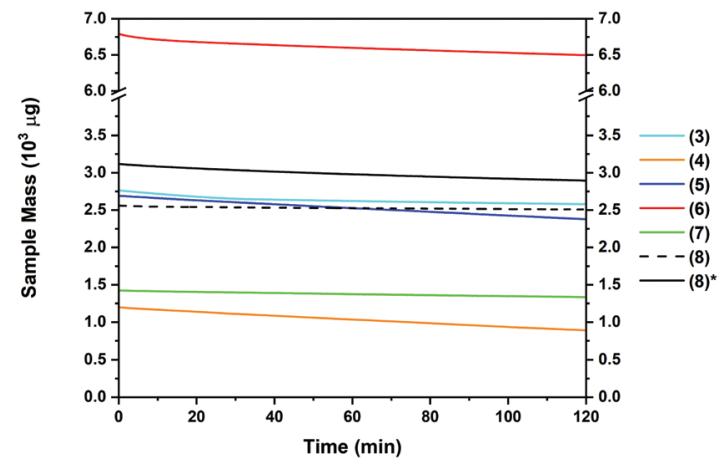

Fig. 6 Mass loss $(\mathrm{mg})$ for complexes $3-8$ over $120 \mathrm{~min}$ at $120^{\circ} \mathrm{C}$ and $160^{\circ} \mathrm{C}^{*}$.

the ethyl and tert-butyl substituted complexes 4 and $\mathbf{5}$ show greatest promise for MOCVD and ALD applications with comparable evaporation rates of $c a .20 \mu \mathrm{g} \mathrm{min}^{-1} \mathrm{~cm}^{-2}$. These values are within a range previously determined to be suitable for a vapour based deposition process. The difference in the evaporation rate between the $s e c-\mathrm{Bu}, n$ - $\mathrm{Bu}$ and $t$-Bu derivatives 5, 6 and 7, respectively, is noticeable, and indicates clearly that not only the molecular mass of a compound but also the factors such as steric crowding, electronic saturation, crystal packing, intermolecular interactions, and so forth, strongly influence thermal behaviour, highlighting the importance of precursor screening. In the case of compound $\mathbf{8}$, which produced the lowest \% residue in the TG analysis (4\%) and demonstrated an unusually high thermal stability $c f$. 1-7 in this series, isothermal analyses were performed at both $130{ }^{\circ} \mathrm{C}$ and $160^{\circ} \mathrm{C}$, respectively, where a significantly higher volatility was observed above the recorded melting point of $153^{\circ} \mathrm{C}$.

It should be noted that these differences would not have been recognised from a standard plot of \% mass loss versus time commonly found elsewhere in the literature, which fails to take into account the differences in mass between the samples, and instead reports the change in mass as a \% of sample size, which is rarely consistent on scales such as these.

\section{Conclusions}

With the use of amine and aldimine substituted pyrroles as chelating ligands, a series of novel homoleptic Sn(II) complexes have been developed. All the compounds are monomeric and volatile, showing variable sublimation behaviour. Given the limited choice of precursors available for MOCVD and ALD of Sn(II) oxide thin films, the ethyl, $t$-butyl and 2,6-di-isopropylphenyl complexes of $\mathbf{4 , 5}$ and $\mathbf{8}$, reported here, are promising precursor candidates for vapour deposition processes.

The work presented here primarily concerns precursor development and molecular characterisation. Detailed studies on the MOCVD and ALD of Sn(II) oxides using these precursors, and subsequent thin film characterisation, will be published separately.

\section{Experimental}

\section{General procedures}

Elemental analyses were performed using an Exeter Analytical CE 440 analyser. ${ }^{1} \mathrm{H},{ }^{13} \mathrm{C}$ and ${ }^{119} \mathrm{Sn}$ NMR spectra were recorded on Bruker Advance 300 or $500 \mathrm{MHz}$ FT-NMR spectrometers, as appropriate, in saturated solutions at room temperature. Chemical shifts are expressed in ppm with respect to $\mathrm{Me}_{4} \mathrm{Si}$ $\left({ }^{1} \mathrm{H}\right.$ and $\left.{ }^{13} \mathrm{C}\right)$. TGA and PXRD analyses were performed using a PerkinElmer TGA7 and Bruker D8 instrument $\left(\mathrm{Cu}-\mathrm{K}_{\alpha}\right.$ radiation), respectively.

All reactions were carried out under an inert atmosphere using standard Schlenk techniques. Solvents were dried and degassed under an argon atmosphere over activated alumina columns using an Innovative Technology solvent purification system (SPS). The $\mathrm{Sn}(\mathrm{II})$ amides, $\left[\mathrm{Sn}\left\{\mathrm{NMe}_{2}\right\}_{2}\right]$ and $[\operatorname{Sn}\{\mathrm{N}$ $\left.\left.\left(\mathrm{SiMe}_{3}\right)_{2}\right\}_{2}\right]$, were prepared by literature methods. ${ }^{27 e, 31}$ The proligands $\mathrm{L}^{1} \mathrm{H}-\mathrm{L}^{7} \mathrm{H}$ were synthesized using literature methods. ${ }^{21}$

Synthesis of $\left.\left[\operatorname{Sn}\left\{\kappa^{2}-N, N^{\prime}-N_{4} \mathbf{H}_{3} \mathrm{CH}_{2} \mathrm{NMe}_{2}\right\} \mathbf{N}\left(\mathrm{SiMe}_{3}\right)_{2}\right\}\right]$ (1). A solution of $\mathrm{L}^{1} \mathrm{H}(0.62 \mathrm{~g}, 5 \mathrm{mmol})$ in hexane $(30 \mathrm{~mL})$ was added to a cooled solution of $\mathrm{Sn}(\mathrm{HMDS})_{2}(2.20 \mathrm{~g}, 5 \mathrm{mmol})$ in hexane $(30 \mathrm{~mL})$. The resulting clear, pale yellow solution was stirred for $3 \mathrm{~h}$ before in vacuo removal of the volatiles and dissolution in fresh hexane. The solution was filtered through Celite ${ }^{\circledR}$ and the volume reduction before storage at $-28{ }^{\circ} \mathrm{C}$ afforded colourless crystals. Yield: $1.13 \mathrm{~g}, 56 \%$. Elemental analysis for $\mathrm{C}_{13} \mathrm{H}_{29} \mathrm{~N}_{3} \mathrm{Si}_{2} \mathrm{Sn}$ (expected): C 38.92 (38.81)\%; H 7.26 (7.27)\%; N 10.48 (10.45)\%. ${ }^{1} \mathrm{H}$ NMR (500 MHz, $\left.\mathrm{C}_{6} \mathrm{D}_{6}\right): 6.96-7.04(\mathrm{~m}, 1 \mathrm{H}$, Pyr, C4-H), 6.54-6.61 (m, 1H, Pyr, C3-H), 6.32-6.38 (m, 1H, Pyr, C2-H), 3.35 (br s, 1H, $\mathrm{CH}_{2}$ ), 1.76 (br s, 6H, NMe $e_{2}$ ), 0.25 (s, 18H, SiMe 3 ). ${ }^{13} \mathrm{C}$ NMR (125.7 MHz, $\mathrm{C}_{6} \mathrm{D}_{6}$ ): 135.5 (1C, Pyr, C1), 125.5, 111.3, 107.5, $60.8\left(1 \mathrm{C}, \mathrm{CH}_{2}\right), 45.3\left(2 \mathrm{C}, \mathrm{NMe} e_{2}\right), 6.7$ (6C, $\left.\mathrm{SiMe}_{3}\right) .{ }^{119} \mathrm{Sn}$ NMR $\left(186.4 \mathrm{MHz}, \mathrm{C}_{6} \mathrm{D}_{6}\right): 49.9$.

Synthesis of $\left[\mathrm{Sn}\left\{\boldsymbol{\kappa}^{2}-N, N^{\prime}-\mathrm{NC}_{4} \mathrm{H}_{3} \mathrm{CH}_{2} \mathrm{NMe}_{2}\right\}_{2}\right]$ (2). A solution of $\mathrm{L}^{1} \mathrm{H}(1.25 \mathrm{~g}, 10 \mathrm{mmol})$ in hexane $(30 \mathrm{~mL})$ was added to a cooled solution of $\operatorname{Sn}(\mathrm{HMDS})_{2}(2.20 \mathrm{~g}, 5 \mathrm{mmol})$ in hexane (30 mL). The resulting clear, pale yellow solution was stirred for $3 \mathrm{~h}$ before in vacuo removal of the volatiles and dissolution in fresh hexane. The solution was filtered through Celite ${ }^{\circledR}$ and the volume reduction before storage at $-28{ }^{\circ} \mathrm{C}$ afforded colourless crystals. Yield: $1.22 \mathrm{~g}, 67 \%$. Elemental analysis for $\mathrm{C}_{14} \mathrm{H}_{22} \mathrm{~N}_{4} \mathrm{Sn}$ (expected): C 45.94 (46.06)\%, H 5.93 (6.07)\%, N 15.22 (15.33)\%. ${ }^{1} \mathrm{H}$ NMR (300 MHz, $\left.\mathrm{C}_{6} \mathrm{D}_{6}\right): 6.99-7.01(\mathrm{~m}, 1 \mathrm{H}$, Pyr, C4-H), 6.59-6.61 (m, 1H, Pyr, C3-H), 6.36-6.39 (m, 1H, Pyr, C2-H), 3.35 (s, $\left.1 \mathrm{H}, \mathrm{CH}_{2}\right), 1.86\left(\mathrm{~s}, 6 \mathrm{H}, \mathrm{NMe} e_{2}\right) \cdot{ }^{13} \mathrm{C} \mathrm{NMR}$ (75.5 MHz, $\mathrm{C}_{6} \mathrm{D}_{6}$ ): 137.0 (1C, Pyr, C1), 125.5 (1C, Pyr, C4), 109.5 (1C, Pyr, C3), 108.0 (1C, Pyr, C2), $59.3\left(1 \mathrm{C}, \mathrm{CH}_{2}\right), 44.8$ (2C, $\left.\mathrm{NMe}_{2}\right) .{ }^{119} \mathrm{Sn}$ NMR $\left(111.8 \mathrm{MHz}, \mathrm{C}_{6} \mathrm{D}_{6}\right):-275.0$.

Synthesis of [ $\left.\mathbf{S n}\left\{\kappa^{2}-N, N^{\prime}-N_{4} H_{3} \mathrm{C}(\mathrm{H}) \mathbf{N M e}\right\}_{2}\right]$ (3). A solution of $\mathrm{L}^{2} \mathrm{H}(1.1 \mathrm{~g}, 10 \mathrm{mmol})$ in hexane $(30 \mathrm{~mL})$ was added to a cooled solution of $\mathrm{Sn}(\mathrm{HMDS})_{2}(2.20 \mathrm{~g}, 5 \mathrm{mmol})$ in hexane $(30 \mathrm{~mL})$. The resulting clear, pale yellow solution was stirred for $3 \mathrm{~h}$ before in vacuo removal of the volatiles and dissolution in fresh hexane. The solution was filtered through Celite ${ }^{\circledR}$ and the volume reduction before storage at $-28{ }^{\circ} \mathrm{C}$ afforded colourless crystals. Yield: $1.45 \mathrm{~g}, 87 \%$. Elemental analysis for 
$\mathrm{C}_{12} \mathrm{H}_{14} \mathrm{~N}_{4} \mathrm{Sn}$ (expected): C 42.96 (43.29)\%, H 4.07 (4.24)\%, N 16.63 (16.83)\%. ${ }^{1} \mathrm{H}$ NMR (500 MHz, $\left.\mathrm{C}_{6} \mathrm{D}_{6}\right): 7.35-7.41(\mathrm{~m}, 1 \mathrm{H}$, PyrCHNMe), 6.97-7.02 (m, 1H, Pyr, C4-H), 6.69-6.74 (m, 1H, Pyr, C3-H), 6.48-6.53 (m, 1H, Pyr, C2-H), 2.83 (s, 3H, $\left.\mathrm{CH}_{3}\right) .{ }^{13} \mathrm{C}$ NMR (75.5 MHz, $\mathrm{C}_{6} \mathrm{D}_{6}$ ): 159.3 (1C, PyrCHNMe), 137.5 (1C, Pyr, C1), 133.3 (1C, Pyr, C4), 117.5 (1C, Pyr, C3), 112.9 (1C, Pyr, C2), $42.4\left(1 \mathrm{C}, \mathrm{CH}_{3}\right) .{ }^{119} \mathrm{Sn}$ NMR $\left(111.8 \mathrm{MHz}, \mathrm{C}_{6} \mathrm{D}_{6}\right):-401.0$.

Synthesis of $\left[\mathrm{Sn}\left\{\kappa^{2}-N, N^{\prime}-\mathrm{NC}_{4} \mathrm{H}_{3} \mathrm{C}(\mathrm{H}) \mathrm{NEt}\right\}_{2}\right](4),\left[\operatorname{Sn}\left\{\kappa^{2}-N, N^{\prime}-\right.\right.$ $\left.\left.\mathrm{NC}_{4} \mathrm{H}_{3} \mathrm{C}(\mathrm{H}) \mathrm{N}^{t} \mathrm{Bu}\right\}_{2}\right]$ (5), $\left[\mathrm{Sn}\left\{\kappa^{2}-N, N^{\prime}-\mathrm{NC}_{4} \mathrm{H}_{3} \mathrm{C}(\mathrm{H}) \mathrm{N}^{s} \mathrm{Bu}\right\}_{2}\right]$ (6) [Sn $\left.\left\{\kappa^{2}-N, N^{\prime}-N_{4} H_{3} \mathrm{C}(\mathrm{H}) \mathbf{N}^{n} \mathrm{Bu}\right\}_{2}\right](7)$ and $\left[\mathrm{Sn}\left\{\kappa^{2}-N, N^{\prime}-\mathrm{NC}_{4} \mathrm{H}_{3} \mathrm{C}(\mathrm{H}) \mathbf{N}\right.\right.$ $\left.\left.\left(2,6-{ }^{\mathrm{i}} \mathbf{P r}_{2} \mathbf{C}_{6} \mathbf{H}_{3}\right)\right\}_{2}\right]$ (8). Complexes 4-8 were prepared in an analogous manner to 3 using $1.22 \mathrm{~g}(10 \mathrm{mmol})$ of $\mathrm{L}^{3} \mathrm{H}, 1.50 \mathrm{~g}$ (10 mmol) $\mathrm{L}^{4} \mathrm{H}, \mathrm{L}^{5} \mathrm{H}, \mathrm{L}^{6} \mathrm{H}$ and $2.54 \mathrm{~g}(10 \mathrm{mmol})$ of $\mathrm{L}^{7} \mathrm{H}$, respectively.

4: Storage at $-28{ }^{\circ} \mathrm{C}$ afforded colourless crystals. Yield: $1.16 \mathrm{~g}, 64 \%$. Elemental analysis for $\mathrm{C}_{14} \mathrm{H}_{18} \mathrm{~N}_{4} \mathrm{Sn}$ (expected): $\mathrm{C}$ 46.46 (46.58)\%, H 4.87 (5.03)\%, N 15.61 (15.52)\%. ${ }^{1} \mathrm{H}$ NMR (500 MHz, $\left.\mathrm{C}_{6} \mathrm{D}_{6}\right): 7.49-7.56(\mathrm{~m}, 1 \mathrm{H}$, PyrCHNEt), 7.04-7.07 (m, 1H, Pyr, C4-H), 6.73-6.77(m, 1H, Pyr, C3-H), 6.50-6.53 (m, 1H, Pyr, C2- $H$ ), 3.18-3.25 (s, 2H, CH $\mathrm{C}_{2}$, 1.03 (t, 3H, $\left.\mathrm{CH}_{3}\right) .{ }^{13} \mathrm{C} \mathrm{NMR}$ (75.5 MHz, $\mathrm{C}_{6} \mathrm{D}_{6}$ ): 156.9 (1C, PyrCHNEt), 137.3 (1C, Pyr, C1), 133.1 (1C, Pyr, C4), 117.4 (1C, Pyr, C3), 112.5 (1C, Pyr, C2), 51.2
(1C, $\left.\mathrm{CH}_{2}\right), 17.3\left(1 \mathrm{C}, \mathrm{CH}_{3}\right) .{ }^{119} \mathrm{Sn}$ NMR (111.8 $\left.\mathrm{MHz}, \mathrm{C}_{6} \mathrm{D}_{6}\right)$ : -402.3 .

5: Storage at $-28{ }^{\circ} \mathrm{C}$ afforded colourless crystals. Yield: $1.69 \mathrm{~g}, 81 \%$. Elemental analysis for $\mathrm{C}_{18} \mathrm{H}_{26} \mathrm{~N}_{4} \mathrm{Sn}$ (expected): C 51.93 (51.83)\%, H 6.15 (6.28)\%, N 13.86 (13.43)\%. ${ }^{1} \mathrm{H}$ NMR $\left(500 \mathrm{MHz}, \mathrm{C}_{6} \mathrm{D}_{6}\right): 7.97-8.02\left(\mathrm{~m}, 1 \mathrm{H}, \operatorname{PyrrCHN}^{t} \mathrm{Bu}\right), 7.19-7.21$ (m, 1H, Pyrr, C4-H), 6.76-6.79 (m, 1H, Pyrr, C3-H), 6.46-6.48 $\left(\mathrm{m}, 1 \mathrm{H}\right.$, Pyrr, C2-H) $1.19\left(\mathrm{~s}, 9 \mathrm{H}, \mathrm{CH}_{3}\right) .{ }^{13} \mathrm{C} \mathrm{NMR}(75.5 \mathrm{MHz}$, $\mathrm{C}_{6} \mathrm{D}_{6}$ ): 154.0 (1C, PyrrCHN ${ }^{t} \mathrm{Bu}$ ), 138.5 (1C, Pyrr, C1), 133.7 (1C, Pyrr, C4), 118.3 (1C, Pyrr, C3), 112.6 (1C, Pyrr, C2), 57.5 (1C, $\left.C\left(\mathrm{CH}_{3}\right)_{3}\right), 31.3\left(3 \mathrm{C}, \mathrm{C}\left(\mathrm{CH}_{3}\right)_{3}\right) .{ }^{119} \mathrm{Sn}$ NMR (111.8 $\left.\mathrm{MHz}, \mathrm{C}_{6} \mathrm{D}_{6}\right)$ : -384.1 .

6: Storage at $-28{ }^{\circ} \mathrm{C}$ afforded colourless crystals. Yield: $1.50 \mathrm{~g}, 72 \%$. Elemental analysis for $\mathrm{C}_{18} \mathrm{H}_{26} \mathrm{~N}_{4} \mathrm{Sn}$ (expected): C 52.13 (51.83)\%, H 6.37 (6.28)\%, N 13.28 (13.43)\%. ${ }^{1} \mathrm{H}$ NMR

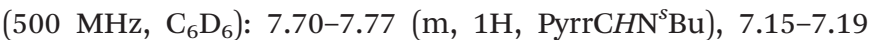
(m, 1H, Pyrr, C4-H), 6.77-6.80 (m, 1H, Pyrr, C3-H), 6.47-6.50 (m, 1H, Pyrr, C2-H), 3.10-3.20 (m, 1H, $\left.-\mathrm{NCH}\left(\mathrm{CH}_{3}\right) \mathrm{CH}_{2} \mathrm{CH}_{3}\right)$, 1.54-1.66 (m, 1H, NCH $\left.\left(\mathrm{CH}_{3}\right) \mathrm{CH}_{2} \mathrm{CH}_{3}\right), 1.36-1.47(\mathrm{~m}, 1 \mathrm{H}, \mathrm{NCH}$ $\left.\left(\mathrm{CH}_{3}\right) \mathrm{CH}_{2} \mathrm{CH}_{3}\right), \quad 1.14-1.19\left(\mathrm{~m}, \quad 3 \mathrm{H}, \quad \mathrm{NCH}\left(\mathrm{CH}_{3}\right) \mathrm{CH}_{2} \mathrm{CH}_{3}\right)$, 0.70-0.75 (m, 3H, NCH $\left.\left(\mathrm{CH}_{3}\right) \mathrm{CH}_{2} \mathrm{CH}_{3}\right) .{ }^{13} \mathrm{C} \mathrm{NMR}(125.7 \mathrm{MHz}$, $\mathrm{C}_{6} \mathrm{D}_{6}$ ): 156.0 (1C, PyrrCHN ${ }^{s} \mathrm{Bu}$ ), 137.6 (1C, Pyrr, C1), 133.7 (1C,

Table 4 X-ray crystallographic data for compounds 1-5 and 8

\begin{tabular}{|c|c|c|c|c|c|c|}
\hline Compound number & 1 & 2 & 3 & 4 & 5 & 8 \\
\hline Chemical formula & $\mathrm{C}_{13} \mathrm{H}_{29} \mathrm{~N}_{3} \mathrm{Si}_{2} \mathrm{Sn}$ & $\mathrm{C}_{14} \mathrm{H}_{22} \mathrm{~N}_{4} \mathrm{Sn}$ & $\mathrm{C}_{12} \mathrm{H}_{14} \mathrm{~N}_{4} \mathrm{Sn}$ & $\mathrm{C}_{14} \mathrm{H}_{18} \mathrm{~N}_{4} \mathrm{Sn}$ & $\mathrm{C}_{18} \mathrm{H}_{26} \mathrm{~N}_{4} \mathrm{Sn}$ & $\mathrm{C}_{34} \mathrm{H}_{42} \mathrm{~N}_{4} \mathrm{Sn}$ \\
\hline Formula mass & 402.26 & 365.04 & 332.96 & 361.01 & 417.12 & 625.40 \\
\hline Crystal system & Monoclinic & Monoclinic & Monoclinic & Monoclinic & Monoclinic & Monoclinic \\
\hline Space group & $P 121 / c 1$ & $P 121 / c 1$ & $P 21 / n$ & $P 21$ & $P 21 / n$ & $P 121 / n 1$ \\
\hline$a / \AA$ & $11.8512(4)$ & $9.3277(3)$ & $13.7265(4)$ & $8.5561(3)$ & $12.1057(3)$ & $15.0740(1)$ \\
\hline$b / \AA$ & $10.4036(3)$ & $11.3766(4)$ & $5.93000(10)$ & $8.8998(3)$ & $9.7711(2)$ & $11.8067(1)$ \\
\hline$c / \AA ̊$ & $15.6557(5)$ & $14.9148(6)$ & $16.1287(4)$ & $10.0193(3)$ & $16.0995(4)$ & $18.2296(2)$ \\
\hline$\alpha /{ }^{\circ}$ & 90 & 90 & 90 & 90 & 90 & 90 \\
\hline$\beta / \circ$ & $96.431(3)$ & $98.662(4)$ & 104.195(3) & $93.866(3)$ & $95.487(2)$ & $106.666(1)$ \\
\hline$\gamma /{ }^{\circ}$ & 90 & 90 & 90 & 90 & 90 & 90 \\
\hline Unit cell volume $/ \AA^{3}$ & 1918.13(11) & $1564.67(10)$ & $1272.76(6)$ & $761.21(4)$ & $1895.62(8)$ & $3108.11(5)$ \\
\hline Crystal size (mm) & $\begin{array}{l}0.403 \times 0.37 \times \\
0.293\end{array}$ & $\begin{array}{l}0.516 \times 0.378 \times \\
0.266\end{array}$ & $\begin{array}{l}0.372 \times 0.040 \times \\
0.028\end{array}$ & $\begin{array}{l}0.320 \times 0.150 \times \\
0.030\end{array}$ & $\begin{array}{l}0.389 \times 0.251 \times \\
0.037\end{array}$ & $\begin{array}{l}0.277 \times 0.238 \times \\
0.196\end{array}$ \\
\hline Temperature/K & $150.00(10)$ & $150.00(10)$ & $150(2)$ & $150(2)$ & $150(2)$ & $150.00(10)$ \\
\hline$Z$ & 4 & 4 & 4 & 2 & 4 & 4 \\
\hline Radiation type & Мo-K $\alpha$ & Mo-K $\alpha$ & $\mathrm{Cu}-\mathrm{K} \alpha$ & $\mathrm{Cu}-\mathrm{K} \alpha$ & $\mathrm{Cu}-\mathrm{K} \alpha$ & $\mathrm{Cu}-\mathrm{K} \alpha$ \\
\hline Theta range $\left({ }^{\circ}\right)$ & 6.54 to 54.958 & 6.586 to 54.958 & 3.797 to 72.307 & 4.423 to 73.010 & 4.375 to 73.438 & 6.732 to 145.674 \\
\hline $\begin{array}{l}\text { Absorption coefficient, } \mu / \\
\mathrm{mm}^{-1}\end{array}$ & 1.451 & 1.627 & 15.833 & 13.285 & 10.746 & 6.741 \\
\hline $\begin{array}{l}\text { No. of reflections } \\
\text { measured }\end{array}$ & 15655 & 13218 & 13015 & 5956 & 12882 & 26377 \\
\hline $\begin{array}{l}\text { No. of independent } \\
\text { reflections }\end{array}$ & 4329 & 3586 & 2487 & 2288 & 3772 & 6142 \\
\hline$R_{\text {int }}$ & 0.0354 & 0.0361 & 0.0405 & 0.0279 & 0.0598 & 0.0393 \\
\hline Final $R_{1}$ values $(I>2 \sigma(I))$ & 0.0295 & 0.0291 & 0.0260 & 0.0336 & 0.0495 & 0.0258 \\
\hline $\begin{array}{l}\text { Final } w R\left(F^{2}\right) \text { values }(I> \\
2 \sigma(I))\end{array}$ & 0.0561 & 0.0563 & 0.0631 & 0.0894 & 0.1407 & 0.0697 \\
\hline Final $R_{1}$ values (all data) & 0.0372 & 0.0381 & 0.0291 & 0.0338 & 0.0536 & 0.0265 \\
\hline $\begin{array}{l}\text { Final } \mathrm{w} R\left(F^{2}\right) \text { values (all } \\
\text { data) }\end{array}$ & 0.0596 & 0.0607 & 0.0646 & 0.0896 & 0.1453 & 0.0702 \\
\hline Goodness of fit on $F^{2}$ & 1.068 & 1.061 & 1.128 & 1.077 & 1.090 & 1.062 \\
\hline $\begin{array}{l}\text { Largest diff. peak and } \\
\text { hole }\left(\mathrm{e} \AA^{-3}\right)\end{array}$ & 0.42 and -0.35 & 0.33 and -0.51 & 1.008 and -0.401 & 1.203 and -0.788 & 1.728 and -0.965 & 0.73 and -0.70 \\
\hline CCDC number & 1820592 & 1820591 & 1820595 & 1820596 & 1820594 & 1820593 \\
\hline
\end{tabular}


Pyrr, C4), 118.2 (1C, Pyrr, C3), 112.7 (1C, Pyrr, C2), 64.3 (br, d, 1C, $\left.\mathrm{NC}\left(\mathrm{CH}_{3}\right) \mathrm{CH}_{2} \mathrm{CH}_{3}\right), 32.3$ (d, 1C, $\left.\mathrm{NC}\left(\mathrm{CH}_{3}\right) \mathrm{CH}_{2} \mathrm{CH}_{3}\right), 22.6$ (d, 1C, $\left.\mathrm{NC}\left(\mathrm{CH}_{3}\right) \mathrm{CH}_{2} \mathrm{CH}_{3}\right), 11.5$ (d, $\left.1 \mathrm{C}, \mathrm{NC}\left(\mathrm{CH}_{3}\right) \mathrm{CH}_{2} \mathrm{CH}_{3}\right) .{ }^{119} \mathrm{Sn}$ NMR (186.4 MHz, $\left.\mathrm{C}_{6} \mathrm{D}_{6}\right)$ : -385.7 .

7: Storage at $-28{ }^{\circ} \mathrm{C}$ afforded colourless crystals. Yield: $1.56 \mathrm{~g}, 75 \%$. Elemental analysis for $\mathrm{C}_{18} \mathrm{H}_{26} \mathrm{~N}_{4} \mathrm{Sn}$ (expected): $\mathrm{C}$ 51.55 (51.83)\%, H 6.20 (6.28)\%, N 13.12 (13.43)\%. ${ }^{1} \mathrm{H}$ NMR $\left(500 \mathrm{MHz}, \mathrm{C}_{6} \mathrm{D}_{6}\right): 7.55-7.61(\mathrm{~m}, 1 \mathrm{H}$, PyrrCHN $n \mathrm{Bu}), 7.09-7.12$ (m, 1H, Pyrr, C4-H), 6.76-6.79 (m, 1H, Pyrr, C3-H), 6.53-6.55 $(\mathrm{m}, 1 \mathrm{H}$, Pyrr, C2-H) $3.26-3.31(\mathrm{t}, J=6.85 \mathrm{~Hz}, 2 \mathrm{H}$, $\left.\mathrm{NCH}_{2} \mathrm{CH}_{2} \mathrm{CH}_{2} \mathrm{CH}_{3}\right), \quad 1.47-1.54\left(\mathrm{~m}, 2 \mathrm{H}, \quad\right.$ PyrrCHNCH $\mathrm{CH}_{2}$ $\left.\mathrm{CH}_{2} \mathrm{CH}_{3}\right), 1.12-1.20\left(\mathrm{~m}, 2 \mathrm{H},-\mathrm{NCH}_{2} \mathrm{CH}_{2} \mathrm{CH}_{2} \mathrm{CH}_{3}\right), 0.79(\mathrm{t}, \mathrm{J}=$ $\left.7.34 \mathrm{~Hz} 3 \mathrm{H}, \mathrm{NCH}_{2} \mathrm{CH}_{2} \mathrm{CH}_{2} \mathrm{CH}_{3}\right) .{ }^{13} \mathrm{C} \mathrm{NMR}\left(125.7 \mathrm{MHz}, \mathrm{C}_{6} \mathrm{D}_{6}\right.$ ): 157.82 (s, 1C, PyrrCHN ${ }^{n} \mathrm{Bu}$ ), 137.6 (1C, Pyrr, C1), 133.5 (1C, Pyrr, C4), 117.8 (1C, Pyrr, C3), 112.9 (1C, Pyrr, C2), 57.4 (1C, $\mathrm{NCH}_{2} \mathrm{CH}_{2} \mathrm{CH}_{2} \mathrm{CH}_{3}$ ), 34.6 (1C, $\left.\mathrm{NCH}_{2} \mathrm{CH}_{2} \mathrm{CH}_{2} \mathrm{CH}_{3}\right), 21.1$ (1C, $\mathrm{NCH}_{2} \mathrm{CH}_{2} \mathrm{CH}_{2} \mathrm{CH}_{3}$ ), $14.3\left(1 \mathrm{C}, \mathrm{NCH}_{2} \mathrm{CH}_{2} \mathrm{CH}_{2} \mathrm{CH}_{3}\right) .{ }^{119} \mathrm{Sn} \mathrm{NMR}$ (186.4 MHz, $\left.\mathrm{C}_{6} \mathrm{D}_{6}\right)$ : -401.5 .

8: Storage at $-28{ }^{\circ} \mathrm{C}$ afforded colourless crystals. Yield: $2.63 \mathrm{~g}, 84 \%$. Elemental analysis for $\mathrm{C}_{34} \mathrm{H}_{42} \mathrm{~N}_{4} \mathrm{Sn}$ (expected): C 65.37 (65.29)\%, H 6.83 (6.77)\%, N 8.91 (8.96)\%. ${ }^{1} \mathrm{H}$ NMR (500 MHz, $\mathrm{C}_{6} \mathrm{D}_{6}$ ): 7.85-7.86 (m, 1H, PyrrCHNDipp), 7.13-7.23 (m, 3H, ortho, meta-Dipp), 6.84-6.86 (m, 1H, Pyrr, C4-H), 6.62-6.64 (m, 1H, Pyrr, C3-H), 6.35-6.37 (m, 1H, Pyrr, C2-H), 3.43 (br s, $1 \mathrm{H}, \mathrm{C} H \mathrm{Me}_{2}$ ), 3.00 (br s, $1 \mathrm{H}, \mathrm{CHMe}$ ), 0.89-1.36 (br, $\left.\mathrm{m}, 12 \mathrm{H}, \mathrm{CHMe} e_{2}\right) .{ }^{13} \mathrm{C} \mathrm{NMR}\left(125.7 \mathrm{MHz}, \mathrm{C}_{6} \mathrm{D}_{6}\right): 158.6$ (1C, PyrrCHNDipp), 149.8 (1C, ipso-Dipp), 145.6 (1C, Pyrr, C1), 142.8 (1C, ortho-Dipp), 142.3 (1C, ortho-Dipp), 137.0 (s, 1C, Pyrr, C3), 126.7 (br, 2C, meta-Dipp), 124.6 (br, 1C, para-Dipp), 121.0 (1C, Pyrr, C4), 114.5 (1C, Pyrr, C2), 29.1 (br, 1C, $C \mathrm{HMe}_{2}$ ), 28.7 (br, 1C, $\mathrm{CHMe}_{2}$ ), 26.4 (br, $\mathrm{CHMe}$ ), 24.9 (br, $\mathrm{CHMe}$ ), 24.6 (br, $\mathrm{CHMe}_{2}$ ), 23.1 (br, $\mathrm{CHMe} e_{2}$ ). ${ }^{119} \mathrm{Sn} \mathrm{NMR} \mathrm{(111.8} \mathrm{MHz,} \mathrm{C}_{6} \mathrm{D}_{6}$ ): -419.0 .

\section{Single crystal X-ray diffraction}

Experimental details related to the single-crystal X-ray crystallographic studies of compounds $\mathbf{1 - 5}$ and $\mathbf{8}$ are summarised in Table 4. All crystallographic data were collected at 150(2) K either on a SuperNova (Dual, EosS2) diffractometer using radiation $\mathrm{Cu}-\mathrm{K} \alpha(\lambda=1.54184 \AA)$ or Mo-K $\alpha(\lambda=0.71073 \AA)$. All structures were solved by direct methods followed by full-matrix least squares refinement on $F^{2}$ using the WINGX-2014 suite of programs $^{32}$ or OLEX2. ${ }^{33}$ All hydrogen atoms were included in idealised positions and refined using the riding model. Crystals were isolated from an argon filled Schlenk flask and immersed in oil before being mounted onto the diffractometer.

The asymmetric unit cell of 3 comprises one molecule of the complex in which all ligand atoms, with the exception of Sn1, N3 and N1, exhibited 80:20 disorder via a pseudo-mirror plane containing the three non-affected atoms. Bond length restraints were included (for chemically equivalent bonds in both the major/minor components), in addition to ADP restraints.

Complex 5 suffers from similar disorder to that observed in 3 , i.e. the asymmetric unit cell comprises one molecule of the complex in which all ligand atoms, with the exception of N3 and N1, exhibited 67:33 disorder via a pseudo-mirror plane containing the three non-affected atoms. Distance-similarity restraints were included (for chemically equivalent bonds in both the major/minor components), in addition to ADP restraints, to assist convergence. The Sn centre is disordered over two sites in the $9: 1$ ratio.

\section{Thermogravimetric analysis (TGA)}

TGA was performed using a TGA 4000 PerkinElmer system, housed in an argon filled glovebox. Samples were prepared air sensitively, and TGAs were performed under a flow of $\mathrm{Ar}$ at $20 \mathrm{ml} \mathrm{min}{ }^{-1}$ and heated from $30{ }^{\circ} \mathrm{C}$ to $400{ }^{\circ} \mathrm{C}$ at a ramp rate of $5^{\circ} \mathrm{C} \min ^{-1}$.

\section{Conflicts of interest}

There are no conflicts to declare.

\section{Acknowledgements}

We acknowledge the financial support from the University of Bath (PhD studentship to J. D. P.) and the Department of Chemistry (Masters studentship to M. W. S.).

\section{References}

1 (a) P. P. Edwards, A. Porch, M. O. Jones, D. V. Morgan and R. M. Perks, Dalton Trans., 2004, 2995; (b) J. Robertson, R. Gillen and S. J. Clark, Thin Solid Films, 2012, 520, 37143720; (c) E. Fortunato, P. Barquinha and R. Martins, Adv. Mater., 2012, 24, 2945-2986; (d) M. Yan, Q. Zhang, Y. Zhao, J. Yang, T. Yang, J. Zhang and X. a. Li, J. Nanosci. Nanotechnol., 2015, 15, 6279-6294; (e) X. Yu, T. J. Marks and A. Facchetti, Nat. Mater., 2016, 15, 383-396; (f) S. A. Miller, P. Gorai, U. Aydemir, T. O. Mason, V. Stevanović, E. S. Toberer and G. J. Snyder, J. Mater. Chem. C, 2017, 5, 8854-8861.

2 K. H. L. Zhang, K. Xi, M. G. Blamire and R. G. Egdell, J. Phys.: Condens. Matter, 2016, 28, 383002.

3 A. N. Banerjee and K. K. Chattopadhyay, Prog. Cryst. Growth Charact. Mater., 2005, 50, 52-105.

4 L. Chen, J. Yang, S. Klaus, L. J. Lee, R. Woods-Robinson, J. Ma, Y. Lum, J. K. Cooper, F. M. Toma, L.-W. Wang, I. D. Sharp, A. T. Bell and J. W. Ager, J. Am. Chem. Soc., 2015, 137, 9595-9603.

5 Z. Wang, P. K. Nayak, J. A. Caraveo-Frescas and H. N. Alshareef, Adv. Mater., 2016, 28, 3831-3892.

6 K. J. Saji, K. Tian, M. Snure and A. Tiwari, Adv. Electron. Mater., 2016, 2, 1500453.

7 Y. Ogo, H. Hiramatsu, K. Nomura, H. Yanagi, T. Kamiya, M. Kimura, M. Hirano and H. Hosono, Phys. Status Solidi A, 2009, 206, 2187-2191. 
8 J. A. Caraveo-Frescas, P. K. Nayak, H. A. Al-Jawhari, D. B. Granato, U. Schwingenschlogl and H. N. Alshareef, ACS Nano, 2013, 7, 5160-5167.

9 (a) D. Das and R. Banerjee, Thin Solid Films, 1987, 147, 321-331; (b) Y. Ogo, H. Hiramatsu, K. Nomura, H. Yanagi, T. Kamiya, M. Hirano and H. Hosono, Appl. Phys. Lett., 2008, 93, 032113; (c) Y. Ogo, H. Hiramatsu, K. Nomura, H. Yanagi, T. Kamiya, M. Kimura, M. Hirano and H. Hosono, Phys. Status Solidi A, 2009, 206, 2187-2191; (d) H. Mu, K. Wang, Z. Zhang and H. Xie, J. Phys. Chem. C, 2015, 119, 10102-10108; (e) B. Kumar, D.-H. Lee, S.-H. Kim, B. Yang, S. Maeng and S.-W. Kim, J. Phys. Chem. C, 2010, 114, 11050-11055.

10 (a) N. Hollingsworth, G. A. Horley, M. Mazhar, M. F. Mahon, K. C. Molloy, P. W. Haycock, C. P. Myers and G. W. Critchlow, Appl. Organomet. Chem., 2006, 20, 687695; (b) H. Uchiyama and H. Imai, Langmuir, 2008, 24, 9038-9042; (c) J. Ning, T. Jiang, K. Men, Q. Dai, D. Li, Y. Wei, B. Liu, G. Chen, B. Zou and G. Zou, J. Phys. Chem. C, 2009, 113, 14140-14144; (d) T. J. Boyle, T. Q. Doan, L. A. M. Steele, C. Apblett, S. M. Hoppe, K. Hawthorne, R. M. Kalinich and W. M. Sigmund, Dalton Trans., 2012, 41, 9349; (e) K. Okamura, B. Nasr, R. A. Brand and H. Hahn, J. Mater. Chem., 2012, 22, 4607; (f) I. Barbul, A. L. Johnson, G. Kociok-Koehn, K. C. Molloy, C. Silvestru and A. L. Sudlow, ChemPlusChem, 2013, 78, 866-874; (g) T. Wildsmith, M. S. Hill, A. L. Johnson, A. J. Kingsley and K. C. Molloy, Chem. Commun., 2013, 49, 8773-8775; (h) M. S. Hill, A. L. Johnson, J. P. Lowe, K. C. Molloy, J. D. Parish, T. Wildsmith and A. L. Kingsley, Dalton Trans., 2016, 45, 18252-18258.

11 H. Viirola and L. Niinistö, Thin Solid Films, 1994, 249, 144149.

12 (a) X. Du, Y. Du and S. M. George, J. Phys. Chem. A, 2008, 112, 9211-9219; (b) X. Du, Y. Du and S. M. George, J. Vac. Sci. Technol., A, 2005, 23, 581-588.

13 J. Sundqvist, J. Lu, M. Ottosson and A. Hårsta, Thin Solid Films, 2006, 514, 63-68.

14 (a) H.-E. Cheng, D.-C. Tian and K.-C. Huang, Procedia Eng., 2012, 36, 510-515; (b) J. W. Elam, D. A. Baker, A. J. Hryn, A. B. F. Martinson, M. J. Pellin and J. T. Hupp, J. Vac. Sci. Technol., A, 2008, 26, 244-252.

15 C. E. Nanayakkara, G. Liu, A. Vega, C. L. Dezelah, R. K. Kanjolia and Y. J. Chabal, Langmuir, 2017, 33, 59986004.

16 (a) J. Heo, A. S. Hock and R. G. Gordon, Chem. Mater., 2010, 22, 4964-4973; (b) M. S. Weimer, B. Hu, S. J. Kraft, R. G. Gordon, C. U. Segre and A. S. Hock, Organometallics, 2016, 35, 1202-1208.

17 J. Heo, S. B. Kim and R. G. Gordon, J. Mater. Chem., 2012, 22, 4599 .
18 J. Tupala, M. Kemell, M. Mattinen, K. Meinander, S. Seppälä, T. Hatanpää, J. Räisänen, M. Ritala and M. Leskelä, J. Vac. Sci. Technol., A, 2017, 35, 041506.

19 J. H. Han, Y. J. Chung, B. K. Park, S. K. Kim, H.-S. Kim, C. G. Kim and T.-M. Chung, Chem. Mater., 2014, 26, 60886091.

20 S. M. George, J. H. Nam, G. Y. Lee, J. H. Han, B. K. Park, C. G. Kim, D. J. Jeon and T.-M. Chung, Eur. J. Inorg. Chem., 2016, 2016, 5539-5546.

21 (a) Y. Yang, D. Cui and X. Chen, Dalton Trans., 2010, 39, 3959; (b) V. V. Grushin and W. J. Marshall, Adv. Synth. Catal., 2004, 346, 1457-1460; (c) B.-C. Xu, T. Hu, J.-Q. Wu, N.-H. Hu and Y.-S. Li, Dalton Trans., 2009, 8854.

22 K. Black, A. C. Jones, J. Bacsa, P. R. Chalker, P. A. Marshall, H. O. Davies, P. N. Heys, P. O'Brien, M. Afzaal, J. Raftery and G. W. Critchlow, Chem. Vap. Deposition, 2010, 16, 93-99.

23 S. Acharya, J. Torgersen, Y. Kim, J. Park, P. Schindler, A. L. Dadlani, M. Winterkorn, S. Xu, S. P. Walch, T. Usui, C. Schildknecht and F. B. Prinz, J. Mater. Chem. C, 2016, 4, 1945-1952.

24 (a) B. Vidjayacoumar, D. J. H. Emslie, J. M. Blackwell, S. B. Clendenning and J. F. Britten, Chem. Mater., 2010, 22, 4854-4866; (b) B. Vidjayacoumar, D. J. H. Emslie, S. B. Clendenning, J. M. Blackwell, J. F. Britten and A. Rheingold, Chem. Mater., 2010, 22, 4844-4853.

25 N. Kuhn, G. Henkel and S. Stubenrauch, J. Chem. Soc., Chem. Commun., 1992, 760.

26 K. Hubler and U. Hubler, Z. Anorg. Allg. Chem., 2000, 626, 1224-1236.

27 (a) G. L. Fondong, E. Y. Njua, A. Steiner, C. F. Campana and L. Stahl, Polyhedron, 2011, 30, 2856-2862; (b) W.-P. Leung, C.-W. So, Y.-S. Wu, H.-W. Li and T. C. W. Mak, Eur. J. Inorg. Chem., 2005, 2005, 513-521; (c) M. Westerhausen, J. r. Greul, H.-D. Hausen and W. Schwarz, Z. Anorg. Allg. Chem., 1996, 622, 1295-1305; (d) J. R. Babcock, L. Liable-Sands, A. L. Rheingold and L. R. Sita, Organometallics, 1999, 18, 4437-4441; (e) T. Fjeldberg, H. k. Hope, M. F. Lappert, P. P. Power and A. J. Thorne, J. Chem. Soc., Chem. Commun., 1983, 639.

28 A. W. Addison, T. N. Rao, J. Reedijk, J. van Rijn and G. C. Verschoor, J. Chem. Soc., Dalton Trans., 1984, 1349-1356.

29 (a) A. Devi, Coord. Chem. Rev., 2013, 257, 3332-3384;

(b) C. Dussarrat, ECS Trans., 2014, 64, 233-241.

30 G. B. Bacskay, M. Martoprawiro and J. C. Mackie, Chem. Phys. Lett., 1999, 300, 321-330.

31 (a) P. Foley and M. Zeldin, Inorg. Chem., 2002, 14, 22642267; (b) M. M. Olmstead and P. P. Power, Inorg. Chem., 1984, 23, 413-415.

32 L. J. Farrugia, J. Appl. Crystallogr., 1999, 32, 837-838.

33 O. V. Dolomanov, L. J. Bourhis, R. J. Gildea, J. A. K. Howard and H. Puschmann, J. Appl. Crystallogr., 2009, 42, 339-341. 